\title{
Comparison of Two Dose Regimens of Intravenous Tissue Plasminogen Activator for Acute Myocardial Infarction
}

\author{
ERIC J. TOPOL, MD, BARRY S. GEORGE, MD, DEAN J. KEREIAKES, MD, \\ RICHARD J. CANDELA, MD, CHARLES W. ABBOTTSMITH, MD, \\ DAVID C. STUMP, MD, JANE M. BOSWICK, MPH, RICHARD S. STACK, MD, \\ ROBERT M. CALIFF, MD, and the TAMI Study Group*
}

Two dosing schedules of intravenous tissue plasminogen activator (t-PA) for acute myocardial infarction were compared in a multicenter trial. At $2.95 \pm$ 1.1 hours from onset of chest pain, 386 patients received $150 \mathrm{mg}$ of intravenous t-PA. For the first 178 patients (group A), $60 \mathrm{mg}$ were given in the first-hour dose and the remaining $90 \mathbf{~ m g}$ were infused over 7 hours. In the subsequent 208 patients (group B), the first-hour dose was $1.0 \mathrm{mg} / \mathrm{kg}$ and the remaining $150 \mathrm{mg}$ were given over 5 hours. At initial angiography $94 \pm \mathbf{3 0}$ minutes into therapy, the infarct vessel patency was $64 \%$ in group $A$ versus $75 \%$ in group $B(p=0.02)$. By final angiography with up to 4 selective contrast injections, patency was $68 \%$ versus $77 \%$, respectively $(p=0.06)$. Repeat angiography at 7 to 10 days demonstrated reocclusion in $17 \%$ of group $A$ and $13 \%$ of group $B$ patients $(p=0.35)$. There was no difference in fibrinogen nadir or mean hematocrit drop between the 2 groups: $120 \mathrm{mg} / \mathrm{dl}$ and 11 points, respective- ly, in group A compared with $120 \mathrm{mg} / \mathrm{dl}$ and 10 points in group B. However, bleeding was reduced in group $B$ patients as evident by a decrease in requirement for $\geq 2$ units of packed red blood cell transfusion (group A $36 \%$, group B $27 \%, p=$ 0.05 ) and lower incidence of gastrointestinal bleeding (group A $12 \%$, group B $4 \%, p=0.002$ ). To further study the importance of weight adjustment, patients were divided into 2 groups according to weight ( $\leq 90 \mathrm{~kg}$ versus $>90 \mathrm{~kg}$ ). According to the results, lighter weight patients had greater transfusion requirements $(35 \%$ versus $20 \%, p=0.006)$ and more frequent major bleeding episodes $(16 \%$ versus $7 \%, p=0.025$ ). Thus, a higher, weight-adjusted first-hour dose of intravenous $t-P A$, with a shorter duration of maintenance infusion, is associated with: (1) improved infarct vessel patency; (2) more rapid recanalization; and (3) less bleeding complications without more fibrinogenolysis.

(Am J Cardiol 1988;61:723-728)

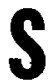
sue-type plasminogen activator ( $t-P A$ ) for myocardial infarction in 1984, there has been considerable growth in our understanding of its pharmacology and a signifi-

From the Department of Internal Medicine, Division of Cardiology, University of Michigan, Ann Arbor, Michigan. This study was supported in part by grants HL35058 and HL01489 from the National Heart, Lung, and Blood Institute, Bethesda, Maryland, and a grant from Genentech, Inc., South San Francisco, California. Manuscript received October 23, 1987; revised manuscript received December 24, 1987, and accepted December 26.

Address for reprints: Eric J. Topol, MD, Division of Cardiology, University of Michigan Medical Center, UH B1 F245, 1500 East Medical Center Drive, Ann Arbor, Michigan 48109-0022.

*'The collaborating centers and investigators are listed in the Appendix. cant change in production methods. Although very low doses of intravenous t-PA were initially used for a brief duration (1 to 3 hours], ${ }^{1-4}$ more recent trials have employed a larger first-hour dose and a prolonged maintenance infusion. 5,6 The initial studies used a predominant 2-chain form of t-PA which was not suitable for large-scale production. The single-chain form of $t$ PA subsequently introduced has a clearance $40 \%$ more rapid than the original preparation and thereby has required a new pharmacologic evaluation for optimal dosing. ${ }^{5}$ Although high doses of this form of intravenous t-PA were demonstrated to promote rapid recanalization, ${ }^{7}$ they were associated with an increascd rate of serious hemorrhagic episodes which led to a recommendation for a decreased dose. 8,9 Thus, controversy exists as to the optimal dosing of this fibrinolytic enzyme for achieving maximal coronary thrombolytic 
TABLE I Comparison of the Two Dose Regimens

\begin{tabular}{|c|c|c|}
\hline & $\begin{array}{c}\text { Group A } \\
(n=178)\end{array}$ & $\begin{array}{c}\text { Group B } \\
(n=208)\end{array}$ \\
\hline Total dose (mg) & 150 & 150 \\
\hline First-hour dose ( $10 \%$ as bolus) & $60 \mathrm{mg}$ & $1.0 \mathrm{mg} / \mathrm{kg}$ \\
\hline Amount (mg) & 90 & 150 - first-hour dose \\
\hline Duration (hr) & 7 & 5 \\
\hline
\end{tabular}

TABLE II Baseline Characteristics*

\begin{tabular}{lcc}
\hline & $\begin{array}{c}\text { Group A } \\
(\mathrm{n}=178)\end{array}$ & $\begin{array}{c}\text { Group B } \\
(\mathrm{n}=206)^{\dagger}\end{array}$ \\
\hline Age (yrs) & $56 \pm 10$ & $56 \pm 11$ \\
Men (\%) & 81 & 76 \\
Weight (kg) & $80 \pm 16$ & $83 \pm 14$ \\
Infarct-related artery (\%) & & \\
Left main & 1 & 0 \\
LAD & 42 & 39 \\
LC & 14 & 12 \\
Right & 43 & 49 \\
Time CP $\rightarrow$ t-PA (hrs) & $2.9 \pm 1.1$ & $3.0 \pm 1.1$ \\
No. of narrowed coronary arteries (\%) & & \\
1 & 54 & 52 \\
2 & 28 & 28 \\
3 & 17 & 18 \\
4 & 1 & 2 \\
Systolic blood pressure (mm Hg) & $134 \pm 25$ & $136 \pm 26$ \\
Heart rate (beats/min) & $82 \pm 18$ & $79 \pm 19$ \\
\hline
\end{tabular}

* There were no significant differences $(p<0.05)$ between groups for the variables listed.

$\dagger$ Although 208 patients were treated with this dosing regimen, 2 did not undergo acute catheterization.

$¥$ Number of major eplcardial vessels with $\geq 50 \%$ stenosis.

$C P=$ chest pain; $L A D=$ left anterior descending; $L C=$ left circumflex.

efficacy with the least possible rate of bleeding complications. The present study was undertaken to determine which of $2 \mathrm{t}-\mathrm{PA}$ dosing regimens employed in a multicenter trial was superior in terms of frequency and speed of coronary artery recanalization, effects on hemostasis and the coagulation system, and the importance of weight adjustment.

\section{Methods}

The Thrombolysis and Angioplasty in Myocardial Infarction (TAMI) study design has been previously described in detail. ${ }^{10}$ To summarize, selection criteria were: (1) patients with $\leq 4$ hours of chest discomfort or severe symptoms with a duration of 4 lo 6 hours, and ongoing pain; and (2) at least $1 \mathrm{~mm}$ of electrocardiographic ST-segment elevation in 2 contiguous leads. Patients were excluded for age $>75$, recent $(<6$ months) trauma, surgery or stroke, prolonged cardiopulmonary resuscitation, prior coronary artery bypass grafting, cardiogenic shock and previous transmural infarction in the same area. All patients provided informed consent and the protocol was approved by the institutional review board at the respective clinical site.
In the trial, the predominantly single-chain form of t-PA was used. ${ }^{5}$ The first 178 patients received an intravenous t-PA dose based on schedule A: $60 \mathrm{mg}$ in the first hour given as a $6-\mathrm{mg}$ bolus and 54-mg drip, and then $20 \mathrm{mg}$ for each of 2 hours, followed by $10 \mathrm{mg} / \mathrm{hr}$ for 5 hours with a total dose of $150 \mathrm{mg}$. In the subsequent 208 patients (schedule B), the same total dose of $150 \mathrm{mg}$ was administered using weight adjustment and a briefer maintenance infusion as follows: $1 \mathrm{mg} / \mathrm{kg}$ for the first hour with $10 \%$ as a bolus and a maximum dose of $90 \mathrm{mg}$, and the remainder of $150 \mathrm{mg}$ over the next 5 hours. The patient's report provided the information on body weight required for dosing. The dose regimens are summarized in Table $I$.

After initiation of t-PA, the patients were transferred to the cardiac catheterization laboratory of the respective clinical site for acute angiography. Nonionic contrast dye was used. The first contrast injection of the infarct vessel was performed after 60 minutes of therapy and images obtained no later than 90 minutes. An exception to the latter occurred when difficulties arose in obtaining arterial access or interhospital transport was delayed. The final determination of infarct vessel patency was made at 90 minutes, after up to 4 injections of the infarct-related artery.

The perfusion status was classified according to the TIMI (Thrombolysis in Myocardial Infarction Study Group) grading system. ${ }^{2}$ For the purpose of this sludy, TIMI 0 and 1 were considered occluded and TIMI 2 or 3 patent. The angiograms were subsequently reviewed at the core angiographic laboratory for verification of the final TIMI grade determination.

On the basis of the 90-minute infarct vessel angiogram, patients were triaged to 3 different groups as follows: (1) persistent occlusion-coronary angioplasty was considered at the discretion of the investigator; (2) patent, $\geq 50 \%$ residual stenosis, suitable for angioplasty - patients were randomized to undergo the procedure immediately or at 7 days; (3) patent, with coronary anatomy unsuilable for angioplasty. Emergency coronary artery bypass surgery was defined as a direct transfer from the cardiac catheterization laboratory during the acute study to the operating room. The procedure was performed for failed percutaneous transluminal coronary angioplasty or high-risk coronary anatomy. In the first 50 patients from the aforementioned groups 1 and 3 , only the first 3 hours of t-PA $(100$ $\mathrm{mg}$ ) were infused (all in group A patients). Angioplasty's complete success was defined as $<50 \%$ residual stenosis and partial success as $\geq 50 \%$ residual stenosis after balloon dilatation.

Concomitant medical therapy consisted of heparin $\{5,000 \mathrm{U}$ at access, $5,000 \mathrm{U}$ at the time of angioplasty if performed acutely, and 500 to $1,000 \mathrm{U} / \mathrm{hr}$ for $\geq 3$ days by continuous infusion adjusted to 2.5 to 3 times the partial thromboplastin time), aspirin ( $325 \mathrm{mg} /$ day), dipyridamole ( $75 \mathrm{mg}, 3$ times daily) and diltiazem ( 30 to $60 \mathrm{mg}, 4$ times daily].

At 7 to 10 days, patients underwent repeat cardiac catheterization to determine infarct vessel patency and left ventriculography. Besides the paired studies, patients returned to the catheterization laboratory be- 
fore 7 days had elapsed if recurrent ischemia occurred, as defined by $\geq 20$ minutes of chest discomfort associated with electrocardiographic changes. After urgent angiography in these patients, who by now had reached a clinical endpoint, either coronary angioplasty or bypass surgery was performed and followed by a repeat (third) cardiac catheterization, whenever possible, hefore hospital discharge. Reocclusion was defined by angiographic documentation of flow pattern as TIMI grade 0 or 1 and flow pattern diagnosed subsequent to established perfusion as TIMI 2 or $3 .^{2}$

Bleeding complications were characterized according to: (1) sitc; (2) nced for transfusion of $\geq 2$ units of packed red blood cells for augmentation of hematocrit $>30$; and (3) baseline and nadir hematocrit values. Gastrointestinal bleeding referred to either guaiacpositive results or frank blood in emesis or stool. Intracranial and retroperiloneal hemorrhage was diagnosed using computed axial tomographic scanning. Assessment of coagulation proteins included assay of the serum fibrinogen by the Clauss and sodium sulfite precipitation methods ${ }^{11,12}$ and the fibrinogen degradation product titer ${ }^{13}$ by tanned red cell agglutination method at baseline, 3, 8 and 12 hours after t-PA.

Statistical analysis: Values are expressed as mean \pm 1 standard deviation unless otherwise specified. Comparison of group A versus group B patients was made using chi-square analysis for dichotomous variables and an unpaired $t$ test or Wilcoxon log-rank test, as specified, for continuous variables. The comparison between the 2 dose regimens was performed with and without those 50 patients in group A who received 100 $\mathrm{mg}$ instead of $150 \mathrm{mg}$ of t-PA. For analysis of the importance of weight $(\leq 90$ or $>90 \mathrm{~kg}$ ), chi-square analysis was used for dichotomous variables, a Wilcoxon ranksum test for continuous variables and a logistic regression model for tosting the relation between the 2 weight groups for multiple variables.

\section{Results}

Study population: The relevant demographic characteristics for the 2 patient groups are summarized in Table II. Patients receiving the 2 different dose regimens were similar with regard to the baseline hemodynamic, angiographic and demographic features.

Patency of the infarct vessel: Table III lists the results for acute and follow-up (before discharge) infarct vessel perfusion status. A significantly higher patency was demonstrated for group B patients at the initial angiogram. As demonstrated in Figure 1, nearly all patients in group $B$ who demonstrated infarct vessel recanalization were already patent at the initial angiogram. The residual stenosis of the infarct vessel was significantly decreased in group B patients compared with group A (Figure 2). The results for initial angiographic patency excluding the 50 patients in group A who did not receive the full $150 \mathrm{mg} t-\mathrm{PA}$ dose were: group A, 68\% patent; group B, 75\% patent; $p=0.16$.

Acute coronary angioplasty was performed in 89 patients in group A and 93 patients in group B with complete or partial success in $73 \%$ versus $83 \%$, respectively $(p=0.09)$. Emergency bypass surgery was neces- sary in $8 \%$ of group A patients compared to $4 \%$ in group $\mathrm{B}(\mathrm{p}=\mathbf{0 . 0 9}$ ). During hospitalization, a total of 39 $(22 \%)$ bypass surgery procedures were performed in group A compared with $44(21 \%)$ in group $B(p=0.19)$. Intraaortic balloon counterpulsation was used in $11 \%$ of group A versus $6 \%$ of group B patients $(p=0.09)$.

Bleeding complications and coagulation system effects: The transfusion requirement, admission and nadir hematocrits, and incidence of bleeding by site appear in Table IV. As shown, the frequency of gastrointestinal bleeding was significantly higher in group A patients. Only 2 patients (both in group B) developed intracranial hemorrhage. Both patients were female with a history of longstanding hypertension, age 68 and 73 , respectively.

In Figure 3, the serum fibrinogen values are plotted for the 2 dosage regimens. There was no difference in the nadir fibrinogen level (120 mg/dl for both groups). The median peak FDP titer was 1:16 in group A versus 1:32 for group B.

Influence of body weight: Patients were divided into 2 groups as shown in Table V. The baseline weight was not recorded in 5 patients enrolled in the trial. As expected, there was a significantly lower proportion of males in the $\leq 90-\mathrm{kg}$ weight column. There were no differences $(p<0.05)$ in patency of the infarct vessel, infarct location, presence of multivessel disease, group A or B dosing or bypass surgery. Lighter weight patients underwent acute coronary angioplasty less fre-
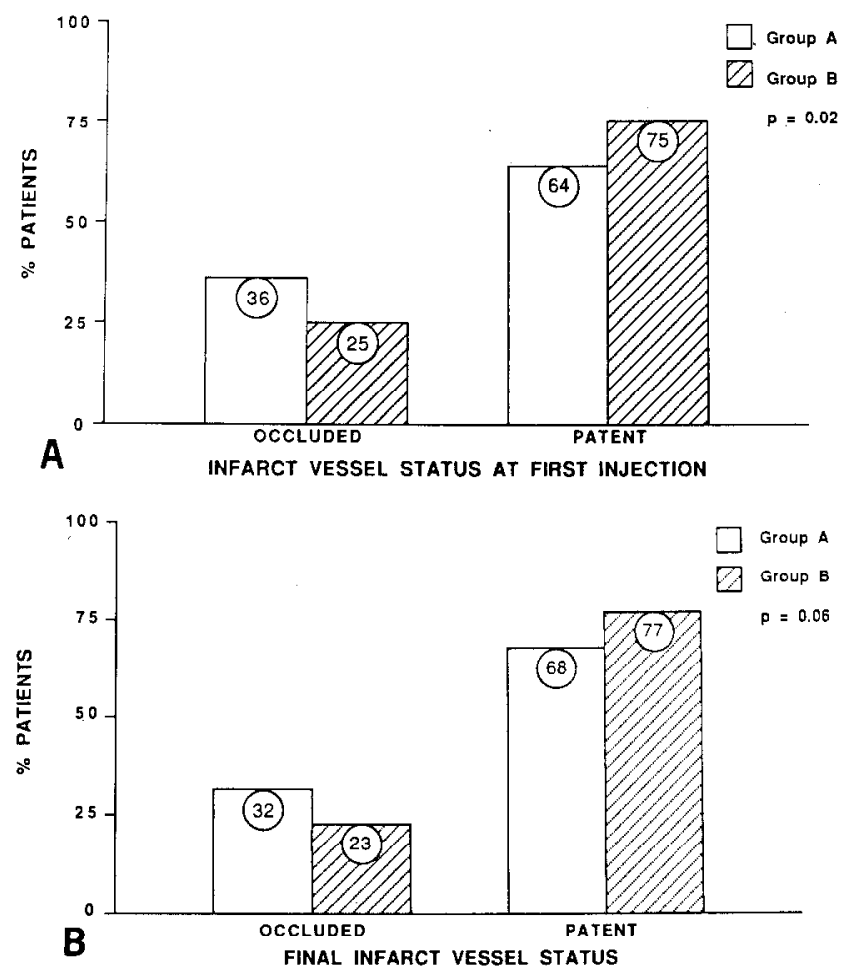

FIGURE 1. A, patency of the infarct vessel on first contrast injection. Group B patients demonstrated a significantly higher patency rate. $B$, patency of the infarct vessel after up to 4 injections at 90 minutes of tissue plasminogen activator ( $t$-PA) therapy. A trend of higher patency was observed for group $B$ patients. 
TABLE III Patency of the Infarct Vessel

\begin{tabular}{lccc}
\hline & $\begin{array}{c}\text { Group A } \\
(n=178)\end{array}$ & $\begin{array}{c}\text { Group B } \\
(n=206)\end{array}$ & $p$ Value \\
\hline $\begin{array}{l}\text { Initial angiogram } \\
\quad \text { Time (min) }\end{array}$ & $94 \pm 31$ & $95 \pm 31$ & 0.61 \\
$\quad$ TIMl 2 or 3 & $110 / 173(64 \%)$ & $153 / 205(75 \%)$ & 0.02 \\
Final angiogram* & & & \\
$\quad$ TIMl 2 or 3 & $119 / 167(68 \%)$ & $157 / 205(77 \%)$ & 0.06 \\
Recurrent ischemic events & $50(28 \%)$ & $56(27 \%)$ & 0.76 \\
Reocclusion on follow-up & $30(17 \%)$ & $28(13 \%)$ & 0.24 \\
$\quad$ angiogram (1 week) & & & \\
\hline
\end{tabular}

* Final angiogram after up to 4 injections of the infarct vessel at the 90minute point of t-PA therapy.

TIMI 2 or $3=$ Thrombolysis in Myocardial Infarction Study Group's grade 2 or 3 (perfusion status patent).

quently ( 45 versus $58 \%$, respectively, $\mathrm{p}=0.023$ ) and had a higher success rate for angioplasty ( 84 versus $68 \%, \mathrm{p}=0.06$.

Despite less invasive procedures performed in the lighter weight patient group (equivalent to a $21 \%$ bypass surgery rate during hospitalization, less acute angioplasty], their transfusion requirement was higher, with major bleeding episodes more frequent as confirmed by a significantly lower nadir hematocrit $\mathrm{Ta}$ ble VJ. In addition, these patients had a lower nadir plasma fibrinogen and a decreased likelihood of reocclusion.

\section{Discussion}

In the current study, 2 different t-PA dose regimens with the same $150 \mathrm{mg}$ cumulative dose were compared. The second regimen, which provided for a weight-adjusted first-hour dose and a lesser duration of maintenance infusion, was found to be superior with respect to frequency and rapidity of infarct vessel patency, decreased transfusion requirement and overall bleeding complications, without more extensive fibrinogenopenia.

Comparison with previous studies: There have been 3 previous trials using the single-chain preparation of t-PA. In the randomized trial of Topol et al, ${ }^{5}$ $0.75 \mathrm{mg} / \mathrm{kg}$ of t-PA was given over the first hour and $0.25 \mathrm{mg} / \mathrm{kg}$ per hour over the subsequent 2 hours. Infarct vessel patency at 90 minutes was $69 \%$ and increased to $79 \%$ at 120 minutes. Using criteria for bleeding complications similar to those adopted in the current study, $29 \%$ received transfusion, gastrointestinal bleeding occurred in $1.1 \%$, genitourinary bleeding in $5 \%$ and the fibrinogen nadir was $62 \%$ of baseline. Reocclusion was not systematically determined but the angiographically confirmed incidence was $20 \%$. As recently reported by Mueller et al, ${ }^{7}$ the open-label Thrombolysis in Myocardial Infarction (TIMI) multicenter trial was divided into 5 separate groups (A through E). In the E phase, 167 patients received a dose of $90 \mathrm{mg}$ over the first hour and $60 \mathrm{mg}$ over the subsequent 4 hours. A high rate of infarct vessel patency resulted $(85 \%$ at $120 \mathrm{~min})$, albeit accompanied by a $1.6 \%$ incidence of intracranial hemorrhage. This re- sulted in a recommendation for a lower dose: $60 \mathrm{mg}$ in the first hour and a cumulative dose of $100 \mathrm{mg}^{8}$

The dose of $150 \mathrm{mg}$ used in the TAMI trial achieved a high proportion of infarct vessel patency without inducing an unacceptable rate of serious bleeding episodes. Although the overall transfusion rate and periaccess bleeding incidence was somewhat higher compared to other trials, all TAMI patients underwent emergent angiography per protocol, with a significant proportion $(21 \%)$ undergoing coronary artery bypass surgery. Nearly all of these patients received transfusion.

First-hour dose: The dose of t-PA in the first hour appears to be a critical determinant of the time of recanalization. As previously demonstrated by TIMI with baseline angiography, increasing the dose from 50 to $90 \mathrm{mg}$ did not yield significantly higher patency at 90 minutes of therapy, but the speed of achieving reperfusion was markedly enhanced. ${ }^{7}$ In the current trial, the higher first-hour dose used in group B was associated with more rapid recanalization and a trend

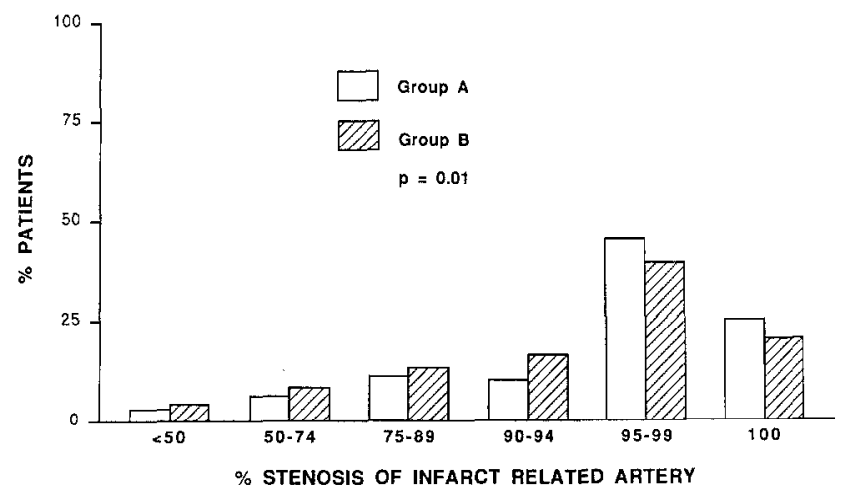

FIGURE 2. Infarct-related artery percent diameter stenosis for group A versus group B patients at the final anglogram obtained during the acute study. A comparison of group A with group B patients shows an overall higher grade residual stenosis for group A.

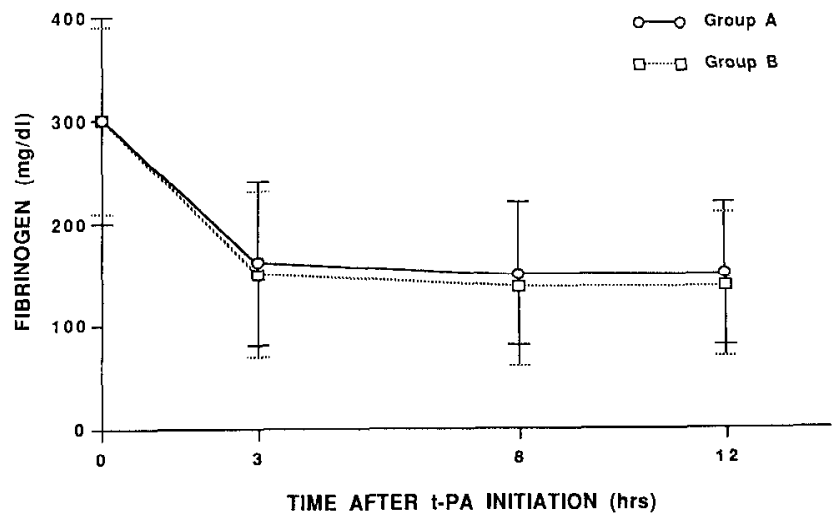

FIGURE 3. Plasma fibrinogen levels (sulfite precipitation method) ${ }^{12}$ versus time after tissue plasminogen activator ( $t-P A)$ therapy. There were no significant differences between the 2 dose groups for nadir fibrinogen values. 
toward a higher proportion of infarct vessel patency at the final angiogram.

Weight adjustment: The results of this study further confirm the importance of a weight-adjusted dose of $\mathrm{t}-\mathrm{PA}$. In previous studies by Topol et al ${ }^{14}$ and Gold and co-workers, ${ }^{6,15}$ the utility of a weight-adjusted dose and its increased safety have been demonstrated. Even though a higher dose was employed in TAMI's group B patients, an overall decreased bleeding complication rate resulted which likely reflects weight adjustment. Patients weighing $<90 \mathrm{~kg}$ had a definite increased risk of bleeding complications compared with heavier patients. In contrast, with a higher weightadjusted first-hour dose of t-PA, there was an increase in rate and proportion of infarct vessel patency. Thus, in order to avoid bleeding episodes and a high transfusion requirement, patients weighing $<60 \mathrm{~kg}$ should probably receive a lower than $60 \mathrm{mg}$ first-hour dose of t-PA. Group B data suggest that patients weighing up to $90 \mathrm{~kg}$ derive benefit from the higher dose in terms of coronary recanalization. Because doses $>90 \mathrm{mg}$ were not given in the first hour, the relative effects of throm. bolysis versus hemorrhage remain speculative in patients $>90 \mathrm{~kg}$.

Maintenance infusion: As demonstrated by Gold et $\mathrm{al}^{6}{ }^{6}$ the purpose of the maintenance infusion is to increase the extent of coronary thrombolysis and limit rethrombosis. The ideal length and dose requirement of such a prolonged infusion have not yet been determined. In 1 recent study, too long an infusion has been reported to yield a high rate of periaccess bleeding that may be unacceptable, ${ }^{16}$ whereas in a recent multicenter trial with a predominant 2-chain form of t.PA, up to a 24-hr low-dose infusion has been tested with apparent low reocclusion and bleeding rate compliçation. ${ }^{17}$

In the current trial, a possible explanation for the increased bleeding observed in patients from group $A$ is the lack of weight adjustment and the duration of maintenance infusion for 7 rather than 5 hours (group B). The additional 2 hours of maintenance infusion may be significant, as reflected by the 3 -fold increase in gastrointestinal bleeding in group A, most of which was initially manifest during the infusion. The increased bleeding with longer maintenance infusions may reflect sustained fibrinolytic action of t-PA. Although the half-life of this t-PA preparation is < 3 minutes, $^{5}$ the beta phase half-life is more than 20 minutes $^{18}$ and this ongoing fibrinolysis proceeds despite physiologic plasma levels of t-PA.19 It would therefore be anticipated that in group A patients there was a considerably longer pharmacologic fibrinolytic effect. Because reocclusion was actually not increased in group $B$ patients, our data suggest that a shorter maintenance infusion of 5 hours may be preferable to 7 hours in achieving the purpose of limiting rethrombosis without promoting bleeding.

Effects of dose on angioplasty success rate: $A$ trend toward a higher success rate in acute coronary angioplasty was observed among group B patients, along with a decrease in the need for emergency bypass surgery. Although this observation may theoretically
TABLE IV Bleeding Complications

\begin{tabular}{lcc}
\hline & $\begin{array}{c}\text { Group A } \\
(\mathrm{n}=178)\end{array}$ & $\begin{array}{c}\text { Group B } \\
(\mathrm{n}=206)\end{array}$ \\
\hline Transfusion & $64(36 \%)$ & $56(27 \%)^{*}$ \\
$>2$ U PRBC & & \\
Admission hematocrit (\%) & $43 \pm 6$ & $44 \pm 4$ \\
Nadir hematocrit (\%) & $31 \pm 6$ & $32 \pm 5$ \\
Gastrointestinal bleeding & $21(12 \%)$ & $8(4 \%)^{\dagger}$ \\
Intracranial bleeding & $0(0 \%)$ & $2(0.9 \%)$ \\
Retroperitoneal bleeding & $1(0.6 \%)$ & $1(0.5 \%)$ \\
\hline
\end{tabular}

$* p=0.05$.

$\dagger p=0.002$.

$\mathrm{U}$ PRBC $=$ units of packed red blood cells.

TABLE V Effect of Body Weight on Bleeding, Coagulation Factors and Rethrombosis

\begin{tabular}{lccc} 
& $\leq 90 \mathrm{~kg}$ & $>90 \mathrm{~kg}$ & p Value \\
\hline No. & 285 & 96 & - \\
Mẹn $^{*}$ & $210(74 \%)$ & $90(94 \%)$ & $<0.001$ \\
Transfused $\geq 2$ U PRBC $_{\text {Major bleeding }}^{\dagger}$ & $99(35 \%)$ & $19(20 \%)$ & 0.006 \\
Reocclusion $_{\text {Nadlr Hct (median) }}$ & $47(16 \%)$ & $7(7 \%)$ & 0.025 \\
Nadir fibrinogen (mg/dl) & $37(13 \%)$ & $21(22 \%)$ & 0.036 \\
$\quad$ (megdian sulfite) & 31 & 33 & $0.0005^{\ddagger}$ \\
& 150 & 179 & $0.0007^{\ddagger}$
\end{tabular}

* Regression analysis has shown that lighter weight, independent of female sex, was associated with increased bleeding risk ${ }^{21}$

†ajor bleeding refers to observed blood loss $>150 \mathrm{ml}$.

$\ddagger$ Continuous variables were analyzed using the Wilcoxon rank-sum test.

Hct $=$ hematocrit; U PRBC $=$ units of packed red blood cells.

be attributed to enhanced coronary thrombolysis (with facilitation of the dilatation procedure), it also may be related to a learning curve phenomenon during the TAMI trial. This point brings up the chief limitation of the current study: although a relatively large sample size at each of the 2 dose schedules was studied, this was a consecutive series and not a randomized comparison. Selection of patients for randomization to angioplasty was determined by the investigators. During the course of the trial, a trend toward decreased randomization to angioplasty and less need for emergency bypass surgcry was noted, so that it remains unclear whether the dose change actually served as a pivotal factor for angioplasty success. ${ }^{20}$

\section{References}

1. Collen D, Topol EJ, Tiefenbrunn AJ, Gold HK, Weisfeldt ML, Sobel BE, Leinbach RC, Brinker JA, Ludbrook PA, Yasuda T, Bulkley BH, Robinsan AK, Hutter AM, Bell WR, Spadaro JI, Khaw BA, Grossbard EB. Coronary thrombolysis with recombinant human tissue-type plasminogen activator: a prospective; randomized, placebo-controlled trial. Circulation 1984;70:10121017.

2. The TIMI Study Group. The thrombolysis in myocardial infarction (TIMI) trial. N Engl I Med 1985;312:932-936.

3. Verstraete M, Bory M, Collen D, Erbel R, Lennane R], Mathey D, Michels IR, Schartl M, Uebis R, Bernard R, Brower RW, de Bono DP, Huhmann W, Lubsen J, Meyer J, Rutsch W, Schmidt W, von Essen K. Kandomized trial of intravenous recombinant tissue-type plasminogen activator versus intravenous streptokinase in acute myocardial infarction. Lancet 1985;1:842-847.

4. Van de Werf F, Ludbrook PA, Bcrgmann SR, Tiefenbrunn $\Lambda$ J, Fox K $\Lambda \Lambda$, de Geest $H$, Verstraete M, Collen D, Sobel BE. Coronary thrombolysis with 
tissue-type plasminogen activator in patients with evolving myocardial infarction. N Eng1 I Med 1984;310:609-613.

5. Topol EJ, Morris D, Smalling R, Schumacher RR, Taylor CR, Nishikawa A, Liberman HA, Collen D, Tufte ME, Grossbard EB, O'Neill WW. A multicenter, randomized, placebo-controlled trial of a new furm of inlravenous recombinant tissue-type plasminogen activator (Activase) in acute myocardial infarction. IACC 1987;9:1205-1213.

6. Gold HK, Leinbach RC, Garabedian HD, Yasuda T, Johns JA, Grossbard EB, Palacios I, Collen D. Acute coronary reocclusion after thrombolysis with recombinant human tissue-type plosminogen activator: prevention by a maintenance infusion. Circulation 1986;73(2):347-352.

7. Mueller HS, Rao AK, Forman SA, the TIMI Investigators. Thrombolysis in myocardial infarction (TIMI): comparative studies of coronary reperfusion and systemic fibrinogenolysis with two forms of recombinant tissue-type plasminogen activator. JACC 1987, in press.

8. Braunwald E, Knatterud GL, Passamani ER, Robertson TL. Announcement of protocol change in thrombolysis in myocardial infarction trial (abstr). JACC 1987;9:467.

9. Grossbard EB. Genetech experience with rt-PA (activase) (abstr]. JACG $1987 ; 9: 467$.

10. Topol FI, Califf RM. Genrge BS, Kereiakes DJ, Abbottsmith CW. Candela R], Lee KL, Pitt B, Stack RS, O'Neill WW, the 'Thrombolysis and Angioplasty in Myocardial Infarction (TAMI) Study Group. A randomized trial of intravenous recombinant tissue plasminogen activator and immediate versus elective angioplasty in acute myocardial infarction. $N$ Engl / Med 1987;317:581-588.

11. Clauss A. Gerinnungsphysiologische Schnellmethode zur Bestimmung des Fibrinogens. Acta Haematol (Basel) 1957;17:237-246.

12. Rampling MW, Galfney PI. The sulphite precipitation method for fibrinogen measurement: its use on small samples in the presence of fibrinogen degradation products. Clin Chim Acta 1976;67:43-52.

13. Mersky C, Lalezari $P$, Johnson AI. A rapid, simple, sensitive method for measuring fibrinolytic split products in human serum. Proc Soc Exp Biol Med 1969;131:871-875.

14. Topol EJ, Bell WR, Weisfeldt ML. Coronary thrombolysis with recombinant tissue-type plasminogen activator: hematologic and pharmacologic study. Ann Intern Med 1985;103:837-843.

15. Garabedian HD, Gold HK, Leinbach RC, Johns JA, Yasuda T, Kanke M Collen D. Comparative properties of two clinical prepuruliuns of recombinant human tissue-type plasminogen activator in patients with acute myocardial infarction. JACC 1987;9:599-607.

16. Gold $\mathrm{HK}$, Johns IA, Leinbach RC, Yasuda T, Grossbard E, Zusman $R$ Collen D. A randomized, blinded, placebo-controlled trial of recombinant human tissue-type plasminogen activator in patients with unstable angina pectoris. Circulation 1987;75:1192-1199.

17. McKee PA. Long term maintenance of recombinant double chain tissue plasminogen activator: prevention of reocclusion after coronary thrombolysis (abstr), Clin Res 1987;76:573A.

18. Eisenberg PR, Sherman $L A$, Tiefenbrunn AJ, Ludbrook PA, Sobel BE, Iaffe AS. Sustained fibrinolysis after administration of t-PA despite its shor holf-life in the circulation. Thromb Haemost 1987;57:35-40.

19. Topol EJ, Ciuffo A $\Lambda$, Pearson TA, Dillman JJ, Builder S, Grossbard E Weisfeldt ML, Bulkley BH. Thrombolysis with recombinant tissue plasminogen activator in atherosclerotic thrombotic occlusion. JACC 1985;5:85-91.

20. O'Neill WW, Kereiakes DJ, Stack RS, George BS, Califf RM, Candela RJ, , Abbottsmith CW, Topol EJ. Cardiothoracic surgical support is required during interventional therapy of myocardial infarction: results from the TAMI study group (abstr). JACC 1987;9:124A

21. Califf RM, Stump D, Thornton D, Kereiakes DJ, George BS, Abbottsmith CW, Candela RJ, Boswick JM, Topol EJ. Hemorrhagic complications after tissue plasminogen activator $[t-P A]$ therapy for acute myocardial infarction. Circulution 1987;76(suppl IV):IV-1.

\section{Appendix \\ Participating Institutions/Investigators}

University of Michigan: Eric J. Topol, MD (principal investigator], William W. O'Neill, MD, Joseph A. Walton, MD, Eric R. Bates, MD, Stephen G. Ellis, MD, M. Anthony Schork, PhD, Eva Kline, RN, BSN, Laura Gorman, RN, BSN, Raymond Worden, BS, Bertram Pitt, MD, and satellite centers in Foote Hospital, Jackson, Michigan: Gregory Baumann, MD, John Maino, MD, Mary Ann Mengleson, MD, Constance Doyle, MD, Patricia Lamb, MD, and South Macomb Hospital, Warren, Michigan: Stanley Wolfe, MD, Leonard Bayer, DO, Armando Madrazo, MD, Robert Moore, MD; Duke University: Robert M. Galiff, MD (co-principal investigator), Richard S. Stack, MD, Harry R. Phillips III, MD, Tomoaki Hinohara, MD, Robert H. Peter, MD, Ken Morris, MD, Victor Behar, MD, Y. Kong, MD, Charles Simonton, MD, Thomas Bashore, MD, Eric Carlson, MD, Susan Mantell, RN, BS, Jane M. Boswick, MPH; Riverside Methodist Hospital: Barry S. George, MD, Richard J. Candela, MD, Joanne Dillon, RN, BS, Ramona Masek, RN, BS; Christ Hospital: Dean J. Kereiakes, MD, Charles W. Abbottsmith, MD, Linda Anderson, RN, BSN, Linda Martin, RN, BSN; William Beaumont Hospital: Gerald C. Timmis, MD, Renato Ramos, MD, V. Gangadharan, MD, Cindy Tollis, RN, BSN; Duke University, Biostatistical Core Laboratory: Jane M. Boswick, MPH, Lynne Aronson, BS, Kerry L. Lee, PhD, Robert M. Califf, MD; University of Michigan, Core Angiographic Laboratory: Raymond Worden, BS, Cindy L. Grines, MD, Mark Sanz, MD, Eric J. Topol, MD; Data Monitoring Committee: Mark Hlatky, MD, Daniel B. Mark, MD, MPH, Kerry L. Lee, $\mathrm{PhD}$; University of Vermont, Core Hematology Laboratory: David Stump, MD, Desire Collen, MD, PhD, Dajnija Thornton, BS. 